\title{
Postoperative cellular stress in the kidney is associated with an early systemic $\gamma \delta$ T-cell immune cell response
}

Ivan Göcze ${ }^{1^{*}} \mathbb{D}$, Katharina Ehehalt ${ }^{2}$, Florian Zeman ${ }^{3}$, Paloma Riquelme ${ }^{1}$, Karin Pfister ${ }^{4}$, Bernhard M. Graf², Thomas Bein ${ }^{2}$, Edward K. Geissler ${ }^{1}$, Piotr Kasprzak ${ }^{4}$, Hans J. Schlitt ${ }^{1}$, John A. Kellum ${ }^{5}$, James A. Hutchinson?', Elke Eggenhofer ${ }^{1}$ and Philipp Renner ${ }^{1}$

\begin{abstract}
Background: Basic science data suggest that acute kidney injury (AKI) induced by ischemia-reperfusion injury (IRI) is an inflammatory process involving the adaptive immune response. Little is known about the T-cell contribution in the very early phase, so we investigated if tubular cellular stress expressed by elevated cell cycle biomarkers is associated with early changes in circulating T-cell subsets, applying a bedside-to-bench approach.

Methods: Our observational pilot study included 20 consecutive patients undergoing endovascular aortic repair for aortic aneurysms affecting the renal arteries, thereby requiring brief kidney hypoperfusion and reperfusion. Clinical-grade flow cytometry-based immune monitoring of peripheral immune cell populations was conducted perioperatively and linked to tubular cell stress biomarkers ([TIMP-2]-[IGFBP7]) immediately after surgery. To confirm clinical results and prove T-cell infiltration in the kidney, we simulated tubular cellular injury in an established mouse model of mild renal IRI.
\end{abstract}

Results: A significant correlation between tubular cell injury and a peripheral decline of $\gamma \delta T$ cells, but no other T-cell subpopulation, was discovered within the first 24 hours $(r=0.53 ; p=0.022)$. Turning to a mouse model of kidney warm $\mathrm{IRI}$, a similar decrease in circulating $\gamma \delta T$ cells was found and concomitantly was associated with a 6.65 -fold increase in

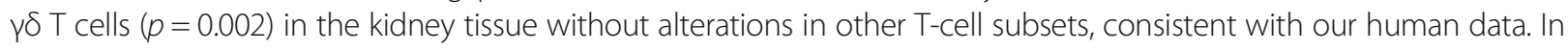
search of a mechanistic driver of $|R|$, we found that the damage-associated molecule high-mobility group box 1 protein HMGB1 was significantly elevated in the peripheral blood of clinical study subjects after tubular cell injury $(p=0.019)$. Correspondingly, HMGB1 RNA content was significantly elevated in the murine kidney.

Conclusions: Our investigation supports a hypothesis that $\gamma \delta$ T cells are important in the very early phase of human AKI and should be considered when designing clinical trials aimed at preventing kidney damage.

Trial registration: ClinicalTrials.gov, NCT01915446. Registered on 5 Aug 2013.

Keywords: Tubular cell stress, Aortic surgery, Immunosurveillance, $ү \delta$ T cells, Ischemia-reperfusion injury

\footnotetext{
* Correspondence: ivan.goecze@ukr.de

${ }^{1}$ Department of Surgery, Surgical Intensive Care and Experimental Surgery,

University Medical Center Regensburg, Regensburg, Germany

Full list of author information is available at the end of the article
}

(c) The Author(s). 2018 Open Access This article is distributed under the terms of the Creative Commons Attribution 4.0 International License (http://creativecommons.org/licenses/by/4.0/), which permits unrestricted use, distribution, and reproduction in any medium, provided you give appropriate credit to the original author(s) and the source, provide a link to the Creative Commons license, and indicate if changes were made. The Creative Commons Public Domain Dedication waiver (http://creativecommons.org/publicdomain/zero/1.0/) applies to the data made available in this article, unless otherwise stated. 


\section{Background}

Discovery of the cell cycle arrest biomarkers TIMP-2 and IGFBP7 (tissue inhibitor of metalloproteinase 2 and insulin-like growth factor-binding protein 7, respectively) enables the early detection of tubular cellular stress [1]. When exposed to stress, epithelial tubular cells may enter a short period of $G_{1}$ cell-cycle arrest until the danger has passed or the injury has been repaired. The urinary biomarkers TIMP-2 and IGFBP7, which are released in stressed cells as an "alarm signal" for adjacent cells, have recently been established as early predictors of imminent acute kidney injury (AKI) in general and postoperative patients [2, 3]. The initiation of early renal protection strategies in patients with elevated stress markers TIMP-2 and IGFBP7 has recently reduced the incidence and severity of postoperative AKI, thus improving the short-term outcome in interventional randomized trials $[4,5]$.

Stressed tubular cells may be sensed by the immune system, similar to oncogenic stress in cancer cells. In cancer, to prevent malignant cellular transformation, stressed human cells are protected through cell-intrinsic barriers, such as induction of cell-cycle arrest and apoptosis, and cell-extrinsic barriers, such as recognition by the immune system and immune elimination [6]. In AKI that has been recognized as a proinflammatory state, equivalent scenarios may exist. Describing this early immune response pathway could have an important impact on future research, including the development of novel therapeutic interventions. Current data suggest that $\mathrm{T}$ cells play a key role in the initiation and propagation of the immune reaction in experimental AKI $[7,8]$.

Therefore, we investigated in our pilot study if tubular cellular stress expressed by elevated cell-cycle arrest biomarkers is associated with early changes in circulating T-cell subsets, using a bedside-to-bench approach. The aim of the study was to obtain the first evidence that this association exists. Renal ischemia-reperfusion injury (IRI) is significantly associated with AKI and also occurs during various surgical procedures in humans, including the treatment of suprarenal aortic aneurysm. In the first part of our study, we evaluated changes in circulating T-cell subsets and their association with tubular cell stress as measured by [TIMP-2]•[IGFPB7] in a clinical setting. Subsequently, findings from the clinical setting were further validated in murine kidneys within the first 24 hours after renal IRI in the experimental part of the study. This bedside-to-bench approach was used to prove the presence of immune cells in kidney tissue and to confirm findings of the pilot clinical study.

\section{Methods}

The study was performed between November 2013 and May 2017 at the University Hospital Regensburg.

\section{Clinical study and patients}

The clinical part of the study was performed first. In this observational study, we included 20 consecutive patients undergoing multibranched endovascular thoracoabdominal aortic repair. Occlusion and intraluminal manipulation of the renal artery during multibranched endovascular aortic repair lead to a brief episode of kidney hypoperfusion and reperfusion. Two patients were excluded: one because of intraoperative interruption of aneurysm repair owing to technical difficulties and one because of requirement of urgent reoperation $<24$ hours after surgery. Eligible patients fulfilled the following four criteria: (1) adults (aged 18 years or older), (2) elective repair of thoracoabdominal aortic aneurysm, (3) presence of a central venous catheter for repeated blood collection, and (4) provision of written informed consent. Exclusion criteria were (1) preexisting liver and kidney failure, defined as a spontaneous international normalized ratio $>2$ and encephalopathy, or serum creatinine $(\mathrm{SCr})>2 \mathrm{mg} / \mathrm{dl}$, or preoperative requirement of renal replacement therapy; and (2) anemia with hemoglobin concentration of $<7 \mathrm{~g} / \mathrm{dl}$.

Ultrasound imaging was conducted at the bedside in a standardized manner. A conventional ultrasound B-scan was followed by color-coded Doppler sonography. Renal perfusion was quantified by mean values of renal resistive index measured in the renal artery and in the interlobar arteries. All examinations were supervised and analyzed at the bedside by a board-certified sonographist, according to German Society for Ultrasound in Medicine guidelines. Postoperative AKI was defined according to the 2012 Kidney Disease: Improving Global Outcomes criteria [9].

The primary endpoint was change in circulating T-cell subsets in subjects with tubular cellular stress. The key secondary endpoints were incidence of AKI, changes in circulating $\mathrm{T}$ cells and cellular infiltration of murine kidneys in histologically proven tubular injury, and values of high-mobility group box 1 (HMGB1) in the clinical and experimental studies.

\section{Collection and analysis of blood and urine}

Blood samples for measuring laboratory parameters such as $\mathrm{SCr}$, creatinine kinase, lactate, hemoglobin, interleukin (IL)-6, C-reactive protein, and central venous oxygen saturation were collected by central venous sampling after the induction of anesthesia, before skin incision, and at prespecified points after surgery (less than 4 hours after the end of surgery and 24 hours after the start of surgery). Urinary [TIMP-2]•[IGFBP7] was measured simultaneously after surgery by means of the immunoassay method integrated in the Astute 140 Meter Kit (Nephrocheck test; Astute Medical Inc., San Diego, CA, USA). A cutoff value of [TIMP-2] $[$ IGFBP7] $\geq 0.3$ was used to identify tubular cellular stress and to predict 
AKI [10]. All values for [TIMP-2]•[IGFBP7] are reported in units of $(\mathrm{ng} / \mathrm{ml})^{2} / 1000$. Blood samples for immune monitoring were collected directly into a Cyto-Chex ${ }^{\circ}$ BCT tube (Streck, Omaha, NE, USA) by central venous sampling after the induction of anesthesia, before skin incision, and 24 hours after the start of surgery. Immediately after collection, the contents of the Cyto-Chex ${ }^{\circ}$ tube were mixed by gentle inversion, and the tube was immediately transported to the in-house immune monitoring laboratory. Samples were typically processed within 30 minutes after blood collection; however, standard operating procedures allowed samples to be stored at $4{ }^{\circ} \mathrm{C}$ for up to 4 hours before processing. To prepare samples for analysis, $100 \mu \mathrm{l}$ of whole blood was transferred from the Cyto-Chex ${ }^{\circ}$ tube into a conical tube (Sarstedt, Nürnbrecht, Germany). Unspecific binding was blocked with $10 \mu \mathrm{l}$ of human FcR blocking reagent (Miltenyi Biotec, Bergisch Gladbach, Germany) in DPBS without $\mathrm{Ca}^{2+}$ or $\mathrm{Mg}^{2+}$ (PAA Laboratories, Cölbe, Germany) and incubated on ice for 30 minutes. Primary conjugated antibodies were added in optimized amounts to stain the cells at $4{ }^{\circ} \mathrm{C}$ for 1 hour. To remove erythrocytes, samples were incubated in $2 \mathrm{ml}$ of $1 \times \mathrm{BD}$ lysing solution (BD Biosciences, Heidelberg, Germany) at $4{ }^{\circ} \mathrm{C}$ for 10 minutes before being washed twice with $2 \mathrm{ml}$ of DPBS. Samples were analyzed using a FACSCanto II cytometer (BD Biosciences) within 30 minutes of antibody staining. As an internal stability control for cytometer performance, a $\mathrm{BD}^{\mathrm{m}}$ Cytometer Setup and Tracking (CST) bead assay (BD Biosciences) was conducted before each analysis. As many $\mathrm{CD} 45^{+}$events as possible were recorded. Data were analyzed by a blinded operator using FlowJo ${ }^{\circ}$ software (FlowJo, Ashland, OR, USA).

\section{Murine ischemia-reperfusion model}

The experimental study was performed after analysis of the clinical data. Six- to 8-week-old C57BL/6 mice (Charles River Laboratories, Sulzfeld, Germany) underwent kidney IRI as described elsewhere [11]. In brief, the renal vessels were exposed bilaterally through a midline incision and occluded with vascular clamps for $30 \mathrm{mi}-$ nutes. During the procedure, animals were kept at a constant temperature $\left(37^{\circ} \mathrm{C}\right)$ and hydrated with warm saline. After 24 hours, the mice were killed, and their organs were harvested for further analysis. Sham-operated animals (controls) were treated identically except for renal artery occlusion. All animal experiments were conducted upon approval by the Government of Upper Palatinate.

\section{Flow cytometry}

In mice, spleens and kidneys were harvested and processed to single-cell suspensions. Renal leukocytes were isolated by mechanically disrupting renal tissue in $5 \mathrm{ml}$ of Paris buffer $(20 \mathrm{mM}$ Tris- $\mathrm{HCl}, 125 \mathrm{mM} \mathrm{NaCl}, 10 \mathrm{mM}$
$\mathrm{KCl}, 10 \mathrm{mM}$ glucose, $\mathrm{pH}$ 7.4). To remove debris, samples were passed through a $100-\mu \mathrm{m}$ cell strainer (Falcon). The resulting cell suspension was centrifuged at $300 \times g$ for 10 minutes to pellet the cells. The pellet was then suspended in 36\% Percoll (Amersham Pharmacia, Stockholm, Sweden), gently overlaid onto $72 \%$ Percoll and centrifuged at $1000 \times g$ for 30 minutes at room temperature. Cells were isolated from the Percoll interface and washed twice in magnetic-activated cell sorting (MACS) buffer at $300 \times g$ at $4{ }^{\circ} \mathrm{C}$ for 10 minutes. Samples were resuspended in $250 \mu \mathrm{l}$ of MACS buffer. The number of leukocytes was assessed using trypan blue exclusion on a hemocytometer. Single-cell suspensions were then stained with antibodies against CD3, CD4, CD8, and $\gamma \delta$ T-cell receptor (eBiosciences, Frankfurt, Germany), and antigen expression was determined with a FACSCanto flow cytometer (BD Biosciences). Data were analyzed with FlowJo software.

\section{Enzyme-linked immunosorbent assay}

Human $H M B G 1$ serum levels were analyzed with a commercially available $H M G B 1$ enzyme-linked immunosorbent assay kit (IBL International, Hamburg, Germany) according to the manufacturer's instructions.

\section{Real-time PCR}

Murine kidney pieces were collected in RNAlater buffer (Qiagen, Hilden, Germany) for further analysis. Complementary DNA (cDNA) was isolated from murine kidney samples using the $\mu$ MACS ONEstep cDNA Kit (Miltenyi Biotec). Relative gene expression changes between GAPDH and HMGB1 were determined by means of the comparative cycle threshold method. The following QuantiTect Primer Sets (Qiagen) were used: QT01658692 for GAPDH and QT02520210 for HMGB1.

\section{Statistical analysis}

No formal sample size calculation was done for the pilot study. A sample size of 20 was expected to yield sufficient power to detect first effects and correlations. Categorical data are presented as absolute numbers and percentages. Continuous data are summarized as mean (SD) or as median (IQR) and were compared using the nonparametric Mann-Whitney $U$ test, if not stated otherwise. Pearson's correlation coefficient was used to assess correlations between continuous variables. The level of significance was set to 5\% without any adjustments for multiple testing. Analyses were conducted using Prism version 6 software (GraphPad Software, La Jolla, CA, USA) and R version 3.2.1 (R Foundation for Statistical Computing, Vienna, Austria). 


\section{Results}

In patients, tubular cellular stress/injury was associated with loss of function

Baseline characteristics are shown in Table 1. A schematic overview of our diagnostic trial is given in Additional file 1: Figure S1a. Nine (50\%) of 18 patients undergoing endovascular aortic repair showed elevated urinary cell stress biomarkers [TIMP-2]•[IGFBP-7] within 4 hours after surgery. On the day after surgery, patients with elevated biomarkers showed a 1.53-fold (SD 0.33) mean increase in creatinine levels compared with baseline values, whereas patients with physiological biomarker levels only showed a 1.13-fold (SD 0.11) mean elevation (Additional file 1: Figure S1b) $(p=0.021)$ and thus had a significantly higher rate of AKI (OR, 12.25; 95\% CI, 1.33-113.06; $p=0.027$ ).

Postoperative renal perfusion was similar in both biomarker groups, as shown by mean arterial pressure over the first 24 hours and standard Doppler sonography. Patients who developed early tubular cell stress required longer duration of surgery and more blood transfusions and had a more positive intraoperative fluid balance, higher vasopressor dose, and higher SOFA score at admission than patients with urinary [TIMP-2][IGFBP-7] $<0.3$ (Table 1, Additional file 1: Figure S1c).

\section{$\gamma \delta \mathrm{T}$ cells were decreased in patient blood with elevated} biomarkers

All patients underwent clinical-grade standardized immune monitoring (Fig. 1a). When comparing $\gamma \delta$ T-cell frequencies before and after surgery, we found that declines in $\gamma \delta$ T-cell frequencies were more pronounced in the patient subset with elevated renal biomarkers (Fig. 1b). Strikingly, the decrease in $\gamma \delta \mathrm{T}$ cells from the circulation correlated with the value of urinary biomarkers (Fig. 1c) $(r=0.53$. $p=0.022)$. There was no correlation of postoperative changes with other T-cell subsets in the first 24 hours. Similar results were found by evaluation of the absolute cell count (Additional file 2: Figure S2) $(r=0.60$, $p=0.01)$.

\section{Murine IRI leads to rapid $\gamma \delta$ T-cell infiltration of the kidneys}

C57BL/6 mice showed a markedly increased level of serum creatinine and urea within the first 24 hours after standardized warm ischemia (Fig. 2a). In parallel, murine kidneys showed histopathological features of early kidney injury (Fig. 2b). Lymphocytes infiltrated the renal interstitium, and infiltrates were analyzed by flow cytometry. $\gamma \delta$ T cells were increased 6.65-fold compared with sham-operated controls $(p=0.002)$ in ischemic kidneys within the first 24 hours after injury, whereas levels of other T-cell subsets tested were similar in both groups (Fig. 2c). Similarly to the human setting, peripheral (blood) murine $\gamma \delta$ T cells were significantly reduced in IRI mice as compared with controls (Fig. 3a left), showing that $\gamma \delta \mathrm{T}$ cells home from blood to the kidneys after cellular injury and induction of IRI.

\section{HMGB1 correlates with murine IRI and human expression of [TIMP-2]•[IGFBP7]}

In search of a mechanistic driver of $\gamma \delta$ T-cell homing, we investigated the role of $H M G B 1$. HMGB1 has recently been described as a potent proinflammatory cytokine released from ischemia-reperfusion-injured cells. HMGB1 messenger RNA (mRNA) expression was significantly increased in murine kidneys within the first 24 hours after IRI (Fig. 3a, right). In humans, HMGB1 protein was significantly elevated in biomarker-positive patients 1 day after surgery compared with biomarker-negative patients (median [IQR] 0.87 [0.68-1.82] versus 2.63 [1.59-12.20] ng/ml, $p=0.019$ ) (Fig. 3b).

\section{Discussion}

In the present study, we investigated the role of human $T$ cells in patients with renal tubular cellular stress and found that the $\gamma \delta$ T-cell subset is involved in the first-line immune response in the very early phase of AKI in both humans and mice. We were able to link the decrease in circulating $\gamma \delta \mathrm{T}$ cells within first 24 hours to elevated cellular stress biomarkers TIMP-2 and IGFBP7 measured 4 hours after surgery, suggesting that stressed/ injured tubular renal cells are recognized early by immune stress surveillance. Accordingly, a drop of $\gamma \delta \mathrm{T}$ cells in the blood of mice was associated with significant cellular infiltration in the murine kidneys within the first 24 hours after cellular injury, suggesting that $\gamma \delta \mathrm{T}$ cells traffic from the blood compartment to injured kidneys. Finally, HMGB1 was elevated in mice and humans and may serve as a link between local cellular injury and aggravation of the systemic inflammatory response.

Injured epithelial cells are recognized by lymphoid stress immunosurveillance $[12,13]$. Interestingly, in humans, $\gamma \delta \mathrm{T}$ cells as a minor fraction of T cells in peripheral blood [14-16] are of increasing importance in early first-line defense in various tissues, such as the skin, brain, liver, and lungs [17-20]. The presence of these cells in murine kidneys has been reported previously, but their role in human AKI is unclear [21].

In patients, perioperative decrease in circulating human $\gamma \delta$ T-cell subpopulations within the first 24 hours after surgery correlated with the values of cell injury biomarkers in our study. No other T-cell subset showed this early correlation. Because only biopsy specimens prove the presence of $\gamma \delta$ T cells in human kidneys during early AKI, and because biopsies are not obtained in the care of these patients, we simulated tubular cell injury in a mouse model of mild renal IRI to prove $\gamma \delta$ T-cell 
Table 1 Baseline perioperative characteristics and outcome parameters

\begin{tabular}{|c|c|c|c|}
\hline Variables & $\begin{array}{l}{[\text { TIMP-2•[|GFBP7] }<0.3} \\
(n=9)\end{array}$ & $\begin{array}{l}{[T I M P-2] \cdot[\mid G F B P 7] \geq 0.3} \\
(n=9)\end{array}$ & $P$ value \\
\hline Age, yr, median (IQR) & $66.7(58.3-71.6)$ & $73.4(69.9-73.9)$ & 0.070 \\
\hline $\mathrm{BMI}, \mathrm{kg} / \mathrm{m}^{2}$, median (IQR) & $28.4(24.8-31.0)$ & $28.1(24.8-31.6)$ & 1.00 \\
\hline Sex, female & 2 & 3 & 0.624 \\
\hline Diabetes mellitus & 1 & 2 & 0.527 \\
\hline Smoking & 6 & 5 & 0.629 \\
\hline Coronary heart disease & 4 & 5 & 0.637 \\
\hline Hypertension & 8 & 8 & 1.000 \\
\hline SAPS II, median (IQR) & $27(20.5-40.0)$ & $34(27.0-53.5)$ & 0.112 \\
\hline SOFA score at admission, median (IQR) & $4.0(1.0-8.0)$ & $8.0(5.0-9.5)$ & 0.045 \\
\hline Ventilation days & $0.0(0.0-1.05)$ & $0.75(0.0-14.7)$ & 0.219 \\
\hline Preoperative IL-6, mg/dl, median (IQR) & $6.15(5.22-20.95)$ & $6.8(5.55-13.10)$ & 0.847 \\
\hline Preoperative hemoglobin, g/dl, median (IQR) & $12.8(11.15-14.25)$ & $12.9(11.05-13.75)$ & 0.965 \\
\hline Preoperative lactate, mg/dl, median (IQR) & $7.4(6.00-8.50)$ & $8.0(7.00-8.60)$ & 0.473 \\
\hline Preoperative $\mathrm{ScvO}_{2}, \%$, median (IQR) & $82.0(77.00-86.65)$ & $86.4(84.35-87.85)$ & 0.077 \\
\hline \multicolumn{4}{|l|}{ Intraoperative values, median (IQR) } \\
\hline Duration of surgery, min & $281.0(203.5-347.0)$ & $422.0(303.0-482.5)$ & 0.031 \\
\hline Intravenous contrast agent, ml & $240.0(150.0-262.5)$ & $250.0(179.25-337.0)$ & 0.469 \\
\hline Urine output, $\mathrm{ml} / \mathrm{h} / \mathrm{kg}$ & $1.6(1.50-2.80)$ & $2.9(1.70-4.75)$ & 0.132 \\
\hline Fluid balance, $\mathrm{ml}$ & $2420(1850-3125)$ & $3350(2915-4474)$ & 0.022 \\
\hline Blood transfusion, ml & $0.00(0.00-0.00)$ & $600.0(0.00-1500)$ & 0.014 \\
\hline Noradrenalin, mg & $0.85(0.34-2.2)$ & $4.6(1.65-6.67)$ & 0.012 \\
\hline MAP below 65 mmHg, \% & $0.00(0.00-7.00)$ & $0.00(0.00-1.90)$ & 0.599 \\
\hline \multicolumn{4}{|l|}{ Postoperative values, median (IQR), at admission ICU } \\
\hline Noradrenalin $\mu \mathrm{g} / \mathrm{kg} / \mathrm{min}$ & $0.06(0.0-0.15)$ & $0.23(0.07-0.30)$ & 0.046 \\
\hline Creatinine, mg/dl & $1.11(0.95-1.39)$ & $0.87(0.71-1.09)$ & 0.112 \\
\hline$\| \mathrm{L}-6, \mathrm{mg} / \mathrm{dl}$ & $66.0(43.25-276.45)$ & $406.9(84.08-856.25)$ & 0.102 \\
\hline Hemoglobin, g/dl & $11.0(9.3-13.35)$ & $10.2(9.80-12.35)$ & 0.627 \\
\hline Lactate $\mathrm{mg} / \mathrm{dl}$ & $9.8(6.10-13.95)$ & $15.0(9.5-18.60)$ & 0.170 \\
\hline $\mathrm{ScvO}_{2}, \%$ & $76.2(71.35-79.25)$ & $78.4(68.3-81.80)$ & 0.427 \\
\hline \multicolumn{4}{|l|}{ Postoperative values, median (IQR), at $24 \mathrm{~h}$} \\
\hline Mean arterial pressure $0-24 \mathrm{~h}$ after admission & $76.1(72.4-87.7)$ & $75.7(68.5-84.7)$ & 0.310 \\
\hline Doppler RI both kidneys at $24 \mathrm{~h}$ & $0.73(0.67-0.76)$ & $0.73(0.72-0.80)$ & 0.232 \\
\hline $\mathrm{IL}-6, \mathrm{mg} / \mathrm{dl}$, at $24 \mathrm{~h}$ & $167.8(31.75-221.00)$ & $185.1(36.20-633.25)$ & 0.354 \\
\hline Hemoglobin, g/dl, at $24 \mathrm{~h}$ & $10.1(8.35-12.5)$ & $9.6(8.4-11.05)$ & 0.930 \\
\hline Lactate, $\mathrm{mg} / \mathrm{dl}$, at $24 \mathrm{~h}$ & $11.4(6.55-14.95)$ & $14.0(10.00-31.00)$ & 0.122 \\
\hline $\mathrm{ScvO}_{2}, \%$, at $24 \mathrm{~h}$ & $68.9(65.4-74.65)$ & $76.2(68.05-81.25)$ & 0.200 \\
\hline Furosemide dose $0-24 \mathrm{~h}, \mathrm{mg}$ & $10.0(0.0 .25 .0)$ & $30.0(5.0-45.0)$ & 0.133 \\
\hline \multicolumn{4}{|l|}{ Outcome parameters } \\
\hline AKI & 2 & 7 & 0.02 \\
\hline AKI Stage 2 and 3 & 0 & 3 & 0.058 \\
\hline RRT & 0 & 2 & 0.134 \\
\hline In-hospital mortality & 0 & 2 & 0.134 \\
\hline
\end{tabular}

Abbreviations: AKI Acute kidney injury, BMI Body mass index, CHD Coronary heart disease, CKD Chronic kidney disease, CK Creatinine kinase, CRP C-reactive protein, $\mathrm{Hb}$ Hemoglobin, IL-6 Interleukin 6, MAP Mean arterial pressure, RRT Renal replacement therapy, SAPS Simplified Acute Physiology Score, SCr Serum creatinine, $\mathrm{ScVO}_{2}$ Central venous oxygen saturation, TIMP-2 Tissue inhibitor of metalloproteinase, IGFBP7 Insulin-like factor-binding protein, $R I$ Resistive index Data are for patients with [TIMP-2]•[IGFBP7] low versus high

Note: Bold $p$ values represent a statistically significant difference between the two groups 


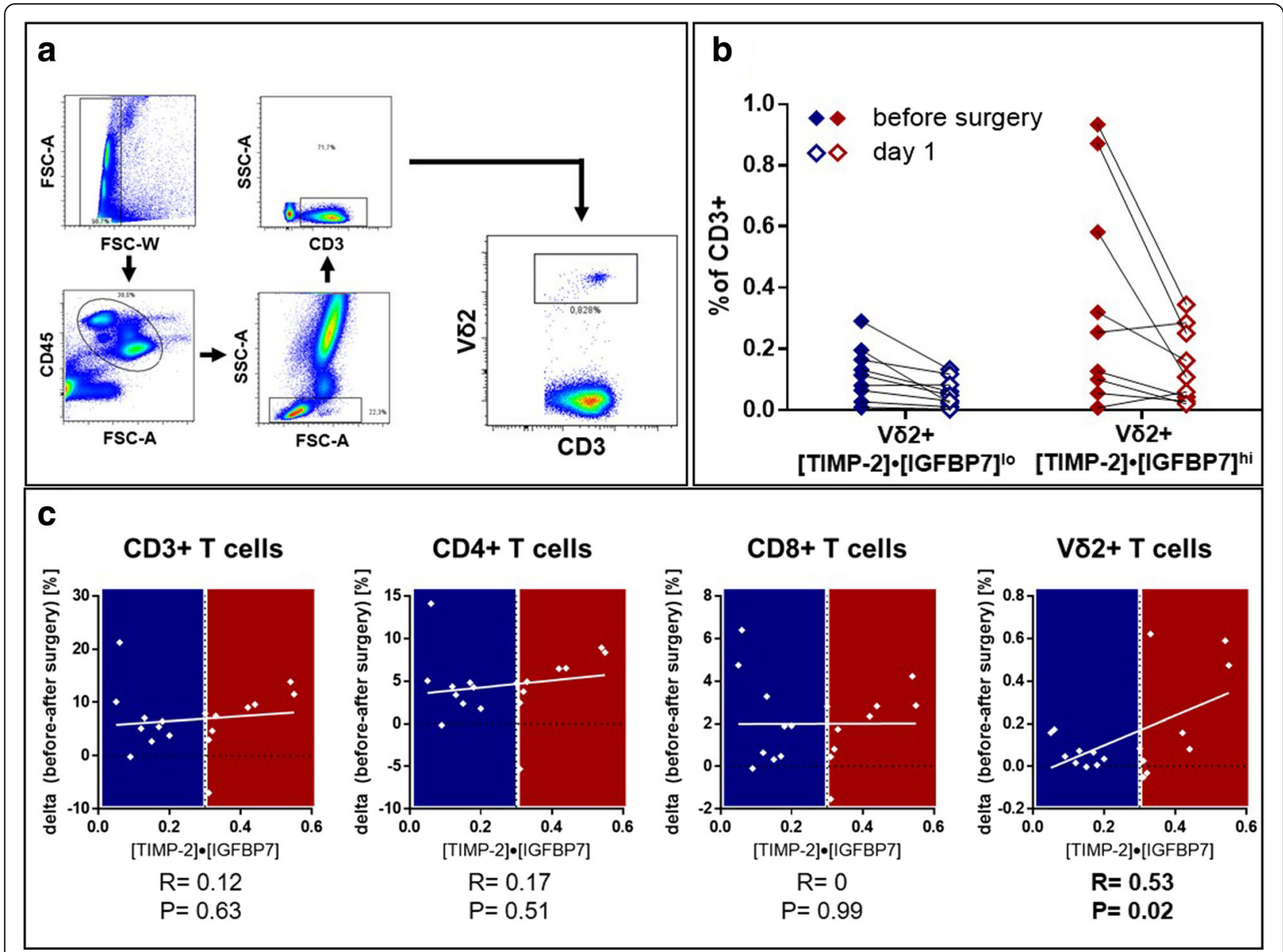

Fig. 1 Correlation between human $\gamma \delta$ T-cell subsets and biomarkers of kidney stress. a Gating strategy used for flow cytometric analysis. Following exclusion of doublets, $C D 45^{+}$cells were analyzed and further specified according to size/granularity. $\gamma \delta \mathrm{T}$ cells were defined as $\mathrm{CD}^{+} \vee \delta 2^{+}$cells. $\mathbf{b}$ Perioperative changes in human peripheral $\gamma \delta \mathrm{T}$-cell frequencies were analyzed and stratified by biomarker results. In patients with elevated biomarkers, greater changes could be observed. c Perioperative changes (postsurgery versus presurgery) of T-cell subsets in human peripheral blood, including $\gamma \delta$ T cells, were correlated with the biomarker level ([TIMP-2]-[IGFBP7]). Here, only changes in the $\gamma \delta$ T-cell subpopulation significantly correlated with biomarker testing $(p=0.022)$, whereas no significant correlation could be observed in the (global) CD3 population or CD4/CD8 T-cell subsets

infiltration in the kidney. Characterization of T-cells subsets isolated from murine kidneys showed that $\gamma \delta \mathrm{T}$ cells were significantly increased within the first 24 hours after IRI, suggesting that these cells traffic to injured kidneys [22]. No early expansion of other tested detected $T$ cells was observed. Therefore, $\gamma \delta$ T cells appear to act as a mediator of early renal IRI, whereas other T-cell subsets, such as CD4 and CD8 cells, are major likely effectors of the immune response at a later stage [23]. This finding may also suggest that the immune response is triggered immediately after cellular stress/injury, hours before the alteration of kidney function can be detected with standard functional markers (such as serum creatinine). Indeed, in a clinical scenario, these cells can be activated upon aseptic tissue damage because they sense danger signals such as phospholipids or markers of cell injury [24]. A very recent analysis of 39 cancer types has shown that intratumoral $\gamma \delta$ T cells are the most significant favorable prognostic immune population owing to their response to stress signals expressed by tumor cells [14]. $\gamma \delta$ T-cell-based immunotherapy has been well tolerated and efficient in clinical trials in patients with advanced renal cell carcinoma [25], underscoring the potential therapeutic use of this cell population for other diseases as well.

Although our findings in both the mouse model and the clinical setting showed that $\gamma \delta$ T cells are involved in the early immune response to kidney injury, it is not clear how this response is triggered. $H M G B 1$ protein released from injured cells may either induce cell-cycle arrest in epithelial cells [26] or modulate the immunological cascade through activating pattern recognition 

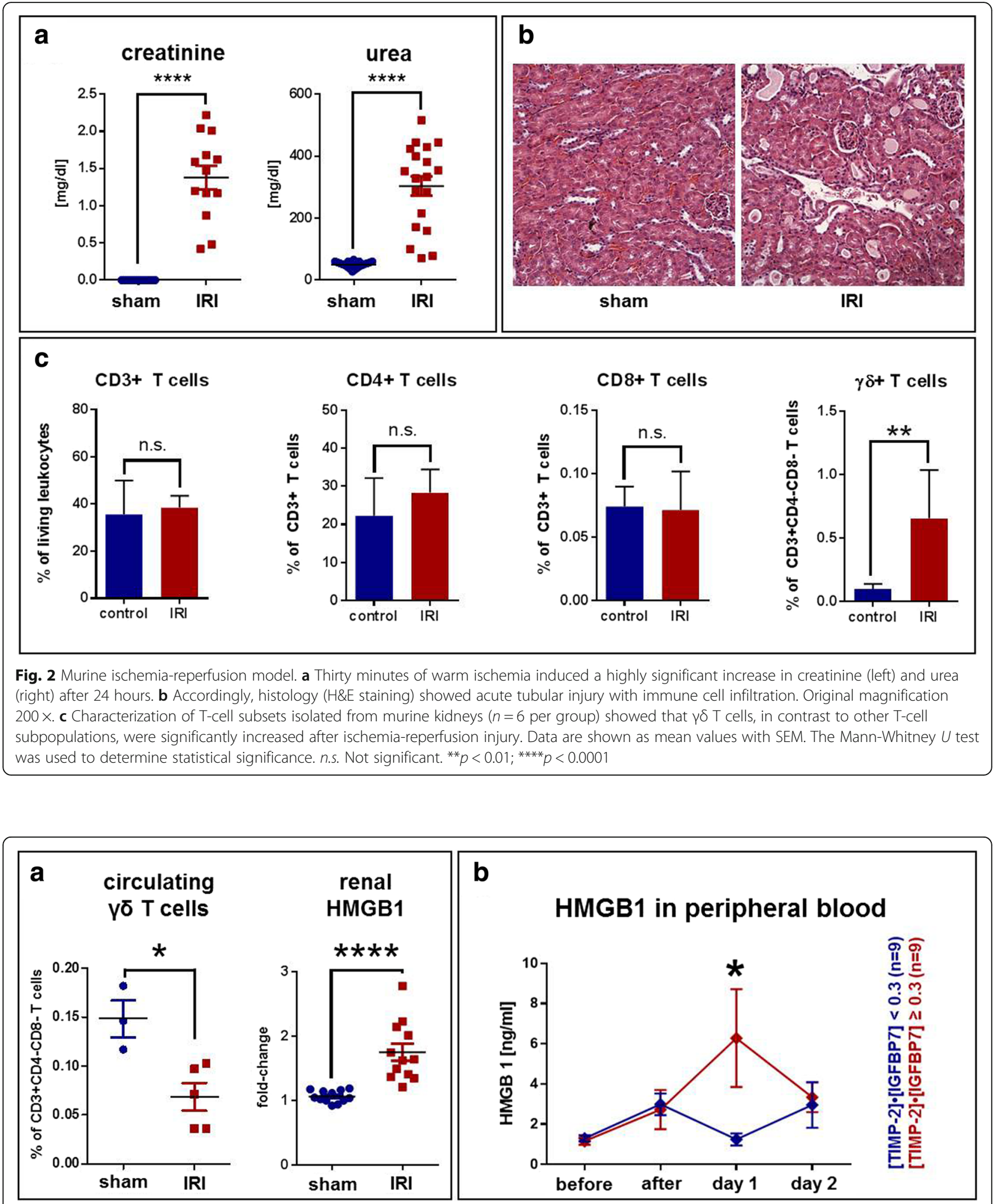

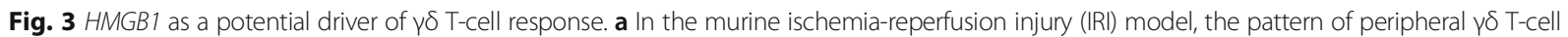
changes was similar to that in the human samples (see Fig. 1c). Here, peripheral $\gamma \delta$ T-cell frequency was significantly reduced after IRI (left, $p=0.036$ ). Interestingly, HMGB1 gene expression was significantly increased in murine kidneys (right, $p<0.0001$ ). b In study participants, the HMGB1 protein was increased in the peripheral blood on day 1 after surgery. Strikingly, biomarker-positive study subjects had significantly higher HMGB1 levels on day 1 than biomarker-negative patients $(p=0.019)$. All data are shown as means with SEM and were evaluated for significance using the Mann-Whitney $U$ test 
receptors in immune cells [22]. Therefore, HMBG1 may serve as a link between cell damage and activation of the systemic inflammatory response [27, 28]. Indeed, HMGB1 mRNA expression was significantly increased in murine kidneys within 24 hours after IRI in our study. Analogously, surgical patients showed a marked HMGB1 increase in [TIMP-2]•[IGFBP7] biomarker-positive patients after 1 day. Although our findings may support the hypothesis that $H M G B 1$ is released from injured epithelial tubular cells, we have not yet examined whether $H M G B 1$ is the driver of $\gamma \delta$ T-cell expansion. However, $H M G B 1$ has already been shown to be critical in inducing IL-17-producing $\gamma \delta \mathrm{T}$ cells via Toll-like receptor 4 (TLR4) activation on macrophages and blockade of $H M G B 1$ suppressed IL- $17^{+} \gamma \delta$ T-cell response $[20,29]$. Furthermore, damage-associated molecular patterns released after tissue/cellular injury are capable of activating dermal and splenic $\gamma \delta$ T cells, leading to increased TLR expression and cytokine, chemokine, and growth factor release $[30,31]$. Our data contribute to the published role of $H M G B 1$ in amplifying inflammation [32-34].

Our study has some limitations. As mentioned above, the ultimate proof of $\gamma \delta \mathrm{T}$-cell infiltration in human kidneys early after AKI may be provided only by timed kidney biopsies that were not available because of the design of our observational trial. Furthermore, although the nine patients in each study group showed unambiguous results, the sample size was small. We also point out that the mouse IRI model and the corresponding homogeneous cohort of patients undergoing endovascular aortic surgery may not be generalizable to all patients with AKI.

\section{Conclusions}

Our bedside-to-bench approach is the first demonstration that $\gamma \delta$ T cells are involved in the early immune response after renal cell injury brought on by IRI in both mice and humans. These cells traffic to the kidney, and their decrease in blood correlates with a greater level of tubular cell injury evidenced by TIMP2 and IGFBP7. $H M G B 1$ is released from injured renal cells and may further amplify the immune reaction. These findings support the hypothesis that the immune response is initiated immediately after cellular stress/injury before AKI becomes evident, and the future immunological interventions may rather be triggered by early cellular injury markers than by standard markers of kidney function. The results of our study may pave the way for future investigation of $\gamma \delta \mathrm{T}$ cells in biomarker-positive patients in larger cohorts of patients. Because human AKI is difficult to prevent in the clinical setting, $\gamma \delta \mathrm{T}$ cells may represent an early marker of systemic immune activation in early AKI and a possible target for future early interventions.

\section{Additional files}

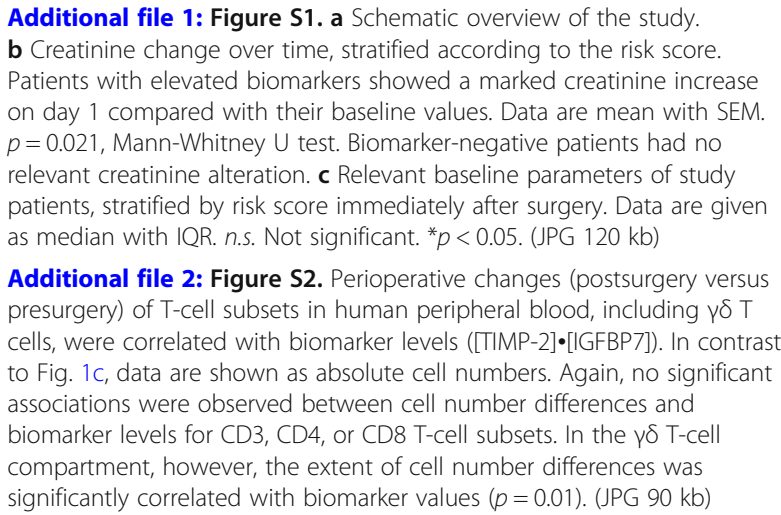

Availability of data and materials

The datasets used and/or analyzed during the current study are available from the corresponding author on reasonable request.

\section{Authors' contributions}

IG, EKG, PK, HJS, EE, and PRe were responsible for the study design and for administering the protocol. KE, IG, PRe, KP, and FZ collected and analyzed the clinical data. EE and PRe performed the experiments and analyzed the experimental data. PRi and JAH performed the immunological analysis. IG, BMG, EKG, HJS, TB, JAK, EE, and PRe wrote and reviewed the manuscript for important intellectual content. All authors read and approved the final manuscript.

\section{Ethics approval and consent to participate}

The study protocol was approved by the local institutional review board (University of Regensburg Ethics Committee, no. 13-101-0027). Written consent was obtained from all patients prior to study entry. The study is registered with ClinicalTrials.gov (NCT01915446).

\section{Consent for publication}

Not applicable.

\section{Competing interests}

JAK has received grant support and consulting fees from Astute Medical unrelated to the current study. IG have received lecture fees from Astute Medical unrelated to the current study. PR was supported by a research grant from the German Interdisciplinary Association of Intensive Care and Emergency Medicine. All of the other authors declare that they have no competing interests.

\section{Publisher's Note}

Springer Nature remains neutral with regard to jurisdictional claims in published maps and institutional affiliations.

\section{Author details}

'Department of Surgery, Surgical Intensive Care and Experimental Surgery, University Medical Center Regensburg, Regensburg, Germany. ${ }^{2}$ Department of Anesthesia, University Medical Center Regensburg, Regensburg, Germany. ${ }^{3}$ Center for Clinical Studies, University Medical Center Regensburg, Regensburg, Germany. ${ }^{4}$ Department of Vascular and Endovascular Surgery, University Medical Center Regensburg, Regensburg, Germany. ${ }^{5}$ Center for Critical Care Nephrology, Department of Critical Care Medicine, University of Pittsburgh, Pittsburgh, PA 15621, USA.

Received: 13 April 2018 Accepted: 12 June 2018

Published online: 04 July 2018

References

1. Kashani K, Al-Khafaji A, Ardiles T, Artigas A, Bagshaw SM, Bell M, Bihorac A, Birkhahn R, Cely CM, Chawla LS, et al. Discovery and validation of cell cycle arrest biomarkers in human acute kidney injury. Crit Care. 2013;17(1):R25. 
2. Bihorac A, Chawla LS, Shaw AD, Al-Khafaji A, Davison DL, Demuth GE, Fitzgerald R, Gong MN, Graham DD, Gunnerson K, et al. Validation of cell-cycle arrest biomarkers for acute kidney injury using clinical adjudication. Am J Respir Crit Care Med. 2014;189(8):932-9.

3. Gocze I, Renner P, Graf BM, Schlitt HJ, Bein T, Pfister K. Simplified approach for the assessment of kidney perfusion and acute kidney injury at the bedside using contrast-enhanced ultrasound. Intensive Care Med. 2015;41(2):362-3.

4. Meersch M, Schmidt C, Hoffmeier A, Van Aken H, Wempe C, Gerss J Zarbock A. Prevention of cardiac surgery-associated AKI by implementing the KDIGO guidelines in high risk patients identified by biomarkers: the PrevAKI randomized controlled trial. Intensive Care Med. 2017:43(11):1551-61.

5. Göcze I, Jauch D, Götz M, Kennedy P, Jung B, Zeman F, Gnewuch C, Graf BM, Gnann W, Banas B, et al. Biomarker-guided intervention to prevent acute kidney injury after major surgery: the prospective randomized BigpAK study. Ann Surg. 2018;267(6):1013-20.

6. Raulet DH, Guerra N. Oncogenic stress sensed by the immune system: role of natural killer cell receptors. Nat Rev Immunol. 2009;9(8):568-80.

7. Andres-Hernando A, Okamura K, Bhargava R, Kiekhaefer CM, Soranno D, Kirkbride-Romeo LA, Gil HW, Altmann C, Faubel S. Circulating IL-6 upregulates IL-10 production in splenic CD4 ${ }^{+} \mathrm{T}$ cells and limits acute kidney injury-induced lung inflammation. Kidney Int. 2017;91(5):1057-69.

8. Weller S, Varrier M, Ostermann M. Lymphocyte function in human acute kidney injury. Nephron. 2017;137(4):287-93.

9. Kellum JA, Lameire N, KDIGO AKI Guideline Work Group. Diagnosis, evaluation, and management of acute kidney injury: a KDIGO summary (Part 1). Crit Care. 2013;17(1):204.

10. Hoste EA, McCullough PA, Kashani K, Chawla LS, Joannidis M, Shaw AD, Feldkamp T, Uettwiller-Geiger DL, McCarthy P, Shi J, et al. Derivation and validation of cutoffs for clinical use of cell cycle arrest biomarkers. Nephrol Dial Transplant. 2014;29(11):2054-61.

11. Linkermann A, Brasen JH, Himmerkus N, Liu S, Huber TB, Kunzendorf U, Krautwald S. Rip1 (receptor-interacting protein kinase 1) mediates necroptosis and contributes to renal ischemia/reperfusion injury. Kidney Int. 2012;81(8):751-61.

12. Chien $\mathrm{YH}$, Meyer C, Bonneville M. $\gamma \delta \mathrm{T}$ cells: first line of defense and beyond. Annu Rev Immunol. 2014;32:121-55.

13. Hayday AC. $\gamma \delta T$ cells and the lymphoid stress-surveillance response. Immunity. 2009;31(2):184-96.

14. Gentles AJ, Newman AM, Liu CL, Bratman SV, Feng W, Kim D, Nair VS, Xu Y, Khuong A, Hoang CD, et al. The prognostic landscape of genes and infiltrating immune cells across human cancers. Nat Med. 2015;21(8):938-45.

15. Shichita T, Sugiyama Y, Ooboshi H, Sugimori H, Nakagawa R, Takada I, I waki T, Okada Y, lida M, Cua DJ, et al. Pivotal role of cerebral interleukin-17-producing $\gamma \delta T$ cells in the delayed phase of ischemic brain injury. Nat Med. 2009:15(8):946-50.

16. Vantourout $P$, Hayday A. Six-of-the-best: unique contributions of gammadelta T cells to immunology. Nat Rev Immunol. 2013;13(2):88-100.

17. Eggenhofer E, Rovira J, Sabet-Baktach M, Groell A, Scherer MN, Dahlke MH, Farkas SA, Loss M, Koehl GE, Lang SA, et al. Unconventional RORyt+ T cells drive hepatic ischemia reperfusion injury. J Immunol. 2013;191(1):480-7.

18. Gelderblom M, Arunachalam P, Magnus T. $\gamma \delta$ T cells as early sensors of tissue damage and mediators of secondary neurodegeneration. Front Cell Neurosci. 2014;8:368.

19. Rani M, Zhang Q, Oppeltz RF, Schwacha MG. Gamma delta T cells regulate inflammatory cell infiltration of the lung after trauma-hemorrhage. Shock. 2015;43(6):589-97.

20. Wang X, Sun R, Wei H, Tian Z. High-mobility group box 1 (HMGB1)-Toll-like receptor (TLR)4-interleukin (IL)-23-IL-17A axis in drug-induced damageassociated lethal hepatitis: interaction of $\gamma \delta T$ cells with macrophages. Hepatology. 2013;57(1):373-84.

21. Savransky V, Molls RR, Burne-Taney M, Chien CC, Racusen L, Rabb H. Role of the T-cell receptor in kidney ischemia-reperfusion injury. Kidney Int 2006;69(2):233-8.

22. Mulay SR, Linkermann A, Anders HJ. Necroinflammation in kidney disease. J Am Soc Nephrol. 2016;27(1):27-39.

23. Kinsey GR, Okusa MD. Role of leukocytes in the pathogenesis of acute kidney injury. Crit Care. 2012;16(2):214.

24. Marlin R, Pappalardo A, Kaminski H, Willcox CR, Pitard V, Netzer S, Khairallah C, Lomenech AM, Harly C, Bonneville M, et al. Sensing of cell stress by human $\gamma \delta$
TCR-dependent recognition of annexin A2. Proc Natl Acad Sci U S A. 2017; 114(12):3163-8.

25. Zou C, Zhao P, Xiao Z, Han X, Fu F, Fu L. $\gamma \delta$ T cells in cancer immunotherapy. Oncotarget. 2017:8(5):8900-9.

26. Zarbock A, Schmidt C, Van Aken H, Wempe C, Martens S, Zahn PK, Wolf B, Goebel U, Schwer Cl, Rosenberger P, et al. Effect of remote ischemic preconditioning on kidney injury among high-risk patients undergoing cardiac surgery: a randomized clinical trial. JAMA. 2015;313(21):2133-41.

27. Chen CB, Liu LS, Zhou J, Wang XP, Han M, Jiao XY, He XS, Yuan XP. Up-regulation of HMGB1 exacerbates renal ischemia-reperfusion injury by stimulating inflammatory and immune responses through the TLR4 signaling pathway in mice. Cell Physiol Biochem. 2017;41(6):2447-60.

28. Rabb H, Griffin MD, McKay DB, Swaminathan S, Pickkers P, Rosner MH, Kellum JA, Ronco C, Acute Dialysis Quality Initiative Consensus XIII Work Group. Inflammation in AKl: current understanding, key questions, and knowledge gaps. J Am Soc Nephrol. 2016;27(2):371-9.

29. Xia Q, Duan L, Shi L, Zheng F, Gong F, Fang M. High-mobility group box 1 accelerates early acute allograft rejection via enhancing $I L-17+\gamma \delta$ T-cell response. Transpl Int. 2014;27(4):399-407.

30. Schwacha MG, Rani M, Nicholson SE, Lewis AM, Holloway TL, Sordo S, Cap AP. Dermal $ү \delta$ T-cells can be activated by mitochondrial damage-associated molecular patterns. PLoS One. 2016;11(7):e0158993.

31. Schwacha MG, Rani M, Zhang Q, Nunez-Cantu O, Cap AP. Mitochondrial damage-associated molecular patterns activate $\gamma \delta$ T-cells. Innate Immun. 2014;20(3):261-8.

32. Goligorsky MS. TLR4 and HMGB1: partners in crime? Kidney Int. 2011:80(5):450-2.

33. Shirali AC, Goldstein DR. Tracking the toll of kidney disease. J Am Soc Nephrol. 2008;19(8):1444-50.

34. Tang D, Kang R, Zeh HJ 3rd, Lotze MT. High-mobility group box 1, oxidative stress, and disease. Antioxid Redox Signal. 2011;14(7):1315-35.

\section{Ready to submit your research? Choose BMC and benefit from:}

- fast, convenient online submission

- thorough peer review by experienced researchers in your field

- rapid publication on acceptance

- support for research data, including large and complex data types

- gold Open Access which fosters wider collaboration and increased citations

- maximum visibility for your research: over $100 \mathrm{M}$ website views per year

At BMC, research is always in progress.

Learn more biomedcentral.com/submissions 